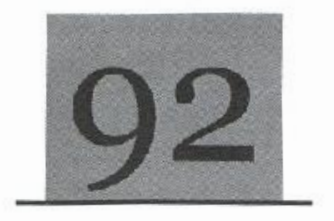

\title{
The role of women in fishery activities in some coastal communities of Rivers State, Nigeria
}

\author{
Cliffe, P. T./Akinrotimi, O. A.
}

\begin{abstract}
Fisheries activities in 10 communities of Rivers State were investigated to determine the role of women in its development and sustainability. Two hundred siructured questionnaires were randomly distributed in three communities (20 per community) across three Local Government Area of the State. The results from the study indicated that young and married women are actively involved in fisheries activities on part time basis, when compared to the older ones. In the siudy area, women are mainly involved in the marketing of fishery products than processing or active fishing. Women are more involved in picking of shell fishes such as oyster, periwinkle at low tide than fishing in creeks and rivers. Fish processing in these communities are done mostly by smoking using a standing oven, which can dry a lot of fish at a time. The marketing strategies adopted by most women in selling their fishery products in the area are open market display and hawking, although, some sell their catch at landing jetties to buyers. Luck of credit facilities, poor transportation network and unsurge in criminal activities have been identified as major constraints facing women involvement in fishery acivities in these areas. There is therefore, the ne'd to empower the women fisher folks in these ureas through granting of loans and credit facilities, capacity building, introduction of new technologies and improved trunsport network systems. These will go a long way in boosting fish production, improve their livelihood and enhance sucio-economic status of the women fisher folks in the coastal communities.
\end{abstract}

Keywords: coastal area, women, fisheries, Food, Rivers State.

\section{Introduction:}

T he fisheries sub- sector is a significant source of fish food and livelihood for many people living in the coastal communities, as it supplies animal protein necessary for growth and income for many households in these rural communities (Akinrotimi et al., 2007). Women have been reported to play a vital role in fishery related activities around the world, especially in the coastal environment, where these activities are classified majorly in three ways; fishing, processing and marketing (Olufayo, 2012). Their role in food production, like coastal fishery has become more relevant as a way of reducing poverty and enhancing food security.

Worldwide, women in fishing communities have been observed to participate actively in fisheries and also play a part in the maintenance of their families (Nwabeze, et al., 2013). In many parts of the world, women have engaged actively in fish business. In the European countries for instance, women control $39 \%$ of the fish industry, making a huge amount of money for themselves and their families (Aguilar, 2002). The crucial engagement of women in natural resources-based occupation such as fisheries in the rural communities has long been accepted, but not recognized, and not valued as men contribution (Obetta et al, 2007).

However, fish production is customarily considered as masculine venture, women role in fish related activities is though supportive, is imperative and indispensable (Cliffe, et al., 2012). However, their role is repeatedly being ignored and relegated, consequent of primordial systems of social setting, that is prevalent in the rural areas of many developing countries like Nigeria (Ibrahim ct al,, 2011). Tamale (2004) reported that the non-recognition of women contribution in production process is enhanced by uneven allocation of resources. Therefore, lack of access and control over productive process is one of the major factors limiting women participation in economic activities such as coastal fishery practices (Acharya, 2003). Women in rural areas participate actively in the traditional fisheries sub-sector of the economy. They are either fully involved or play a complementary role for men in provision for their families. There is therefore the need to promote and to encourage women folk in this sector, so as to boost supply of food fish and improve the cconomic welfare of their families (I.F.A.D., 
2008; Ekpo, 2013).

Fisheries is an important activity, that is predominant in the coastal areas of Rivers State, the role of women in fisheries related activities in these areas are very crucial and critical to the overall economy of the state, but policy maker usually overlook the important role that women play in fisheries activities. This paper therefore, evaluates the role of women in coastal fisheries in some coastal communities of Rivers state as an important tool for boosting food security and improving the livelihood of the people in these communities.

\section{Materials and Methods}

The study was conducted in 10 coastal communities namely Buguma, Ido, Abalama, Tema, Okpo and Tlelema (Asari Toru Local Government Area), Obuama and Degema (Degema. Local Government Area); Abonnema and Obonoma (Akuku-Toru Local Government Area) all in Rivers State, Nigeria. These areas are surrounded by large water bodies and the vegetation in this area varies from mangrove to evergreen swamp forest. The prevailing climatic condition thus favours a thriving fishery activity.

Data were collected with the aid of structured questionnaires, following the method described by F $\Lambda$ O (1999). It was distributed 20 per community, making it a total of 200 questionnaires. Questionnaires were administered only to female fisher folks, and they were interviewed at mangrove swamps, jetties, fish landing spots, smoking hut, houses and market squares. The structured questionnaires were used to extract the socio-economic characteristics which include; age, marital status, household numbers, educational level, year of fishing experience, type of fishery activities and the constraints facing the fisher folks. Completed questionnaire were collated and analyzed using descriptive statistical tool, involving the use of central tendency such as frequency, percentage and charts to explain the various variable of interest.

\section{Results and Discussion}

The results of the respondents in the study area indicated that women participation in fisheries activities increased greatly among the youths, within the age bracket of 20 to 40 ; with the highest percentage $(32.5 \%)$ recorded in the age bracket of 31-40, (Figure 1). A decreasing trend of participation was equally observed as the age of the women advanced, with the lowest $(5.0 \%)$ in women above 60 years old (Figure 1). This result is in line with that of Akinrotimi et al. (201 1a) who observed same in some fishing communities of Niger Delta. This may be due to the fact, fishery activities are energy demanding jobs, so the women need to be physically strong to accomplish most of the tasks. The educational status of the women in this study revealed that most of them (55\%) had secondary education and while a few of them (3\%) had tertiary education (Figure 2). This result confirms the one obtained by Williams (2006) that women from fisher communities are not well-read, with little or no education. Majority ( $42 \%$ ) of the women interviewed in this study are married, about $40 \%$ are single, $4 \%$ are divorcee, and $2 \%$ widowed (Figure 3 ).
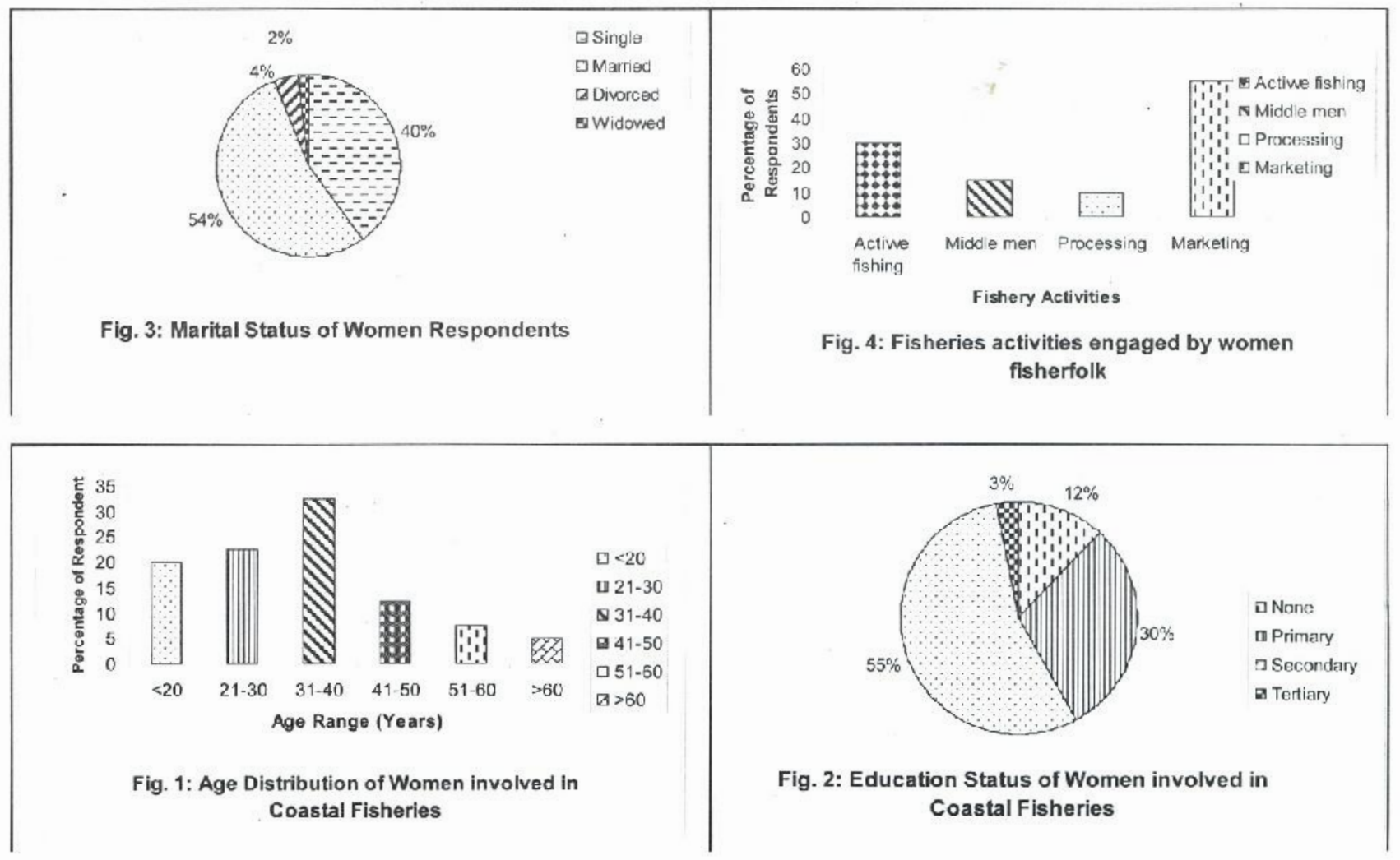

These results agree with the findings of Nwabeze et al. (2013) in women participation in fisheries of Kainji Lake basin. They attributed the dominance of married women in fishery activities to an act of proactivity on the parts of the women in ensuring food security, generate income and reduced feminine vulnerability within the family. The fisheries activities engaged 
by women folk in the study area is shown in Figure 4. From the results, it was discovered that most women (55.0\%) engaged in marketing, $30 \%$ of them in active fishing, while $15 \%$ served as middlemen between active fishers and buyers and $10 \%$ were involved in fish processing. This result corroborated that of Odulate et al. (2011) who reported a similar trend in the coastal wetland areas of Ogun state, Nigeria Ile observed that women are more involved in fish marketing than other fishery activities. Considering the type of fishing activities engaged by women fisher folk in this work, majority (50\%) of the women engaged in picking of shell fish, while $40 \%$ and $10 \%$ participated in setting of traps fishing in creeks/rivers respectively, with zero percent observed in deep sea fishing (Figure 5). This result corroborate that of Akinrotimi and Edun (2011) who reported that women in the coastal area of Rivers State are actively involved in picking of shell fishes, such as periwinkle, oyster and clam. From this study, engagement of women is limited to the creeks and rivers, it is forbidden for women to be involved in deep sea fishing in the coastal area of Niger Delta (Akinrotimi et al., 2006). Figure 6 shows that most of the women (50\%) had eleven to twenty years experience, only $2 \%$ had above forty years. This result followed this trend, since most of the fisher women are in thcir youthful age.

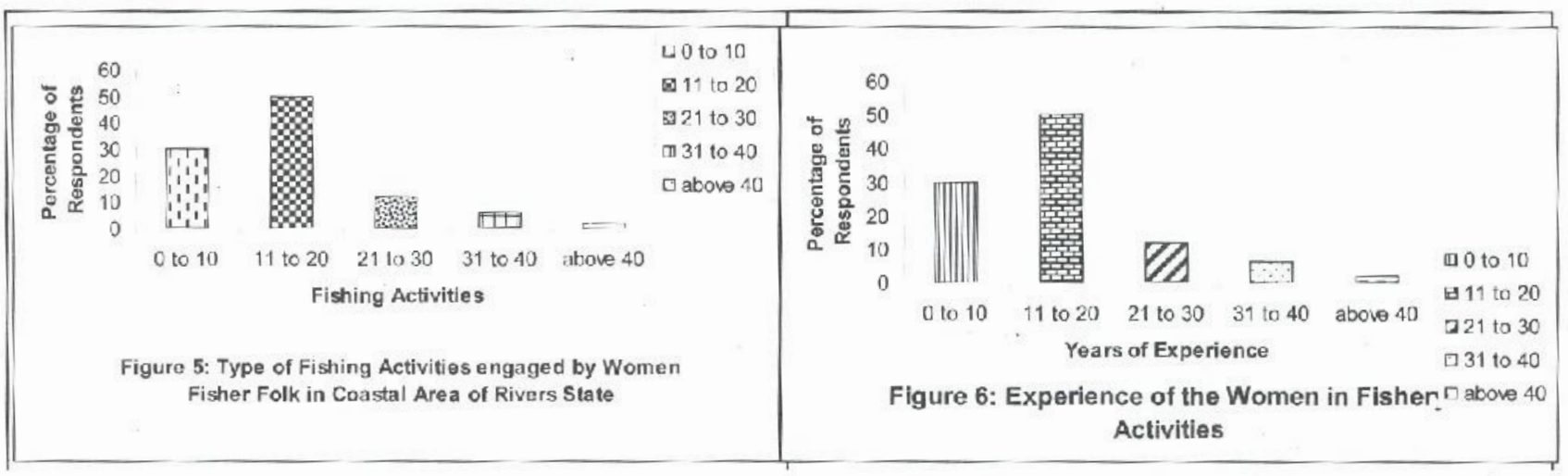

The reasons for the fisher women involvement in coastal fisheries activitics is shown in Figure $7(63 \%)$ of respondents are engaged in coastal fisheries to meet their daily needs, such as feeding, taking care of their children and lending a helping hand to support their husbands.

The desire to purchase goods for sale $(20 \%)$ is closely followed by their propensity to generate savings (15\%) and lastly by their aspiration to pay school fees. This is in line with the findings of Cliffe et al. (2011a), in some rural communities of Niger Delta. They altributed the main reason for women participation in fisheries to their longing to meet their daily needs. The reason why school fees recorded low response may be due to free education scheme of the State Government.

The mode of operation of women fisher folks in the coastal area of Rivers state indicated that $(65 \%)$ of women are engaged in fishery business on part time basis, while (27\%) on full time and (8\%) does it occasionally (Figure 8 ). This result agrees with the findings of Akinrotimi et al. (2011b) in the same study area. The reason may be due to declining returns from artisanal fisheries being witnessed in recent times. There is the need for them to diversify. As livelihood diversification according to Cochrane ct al. (2009) is a veritable means of risk transfer and reduction in the level of burden in times of crisis.
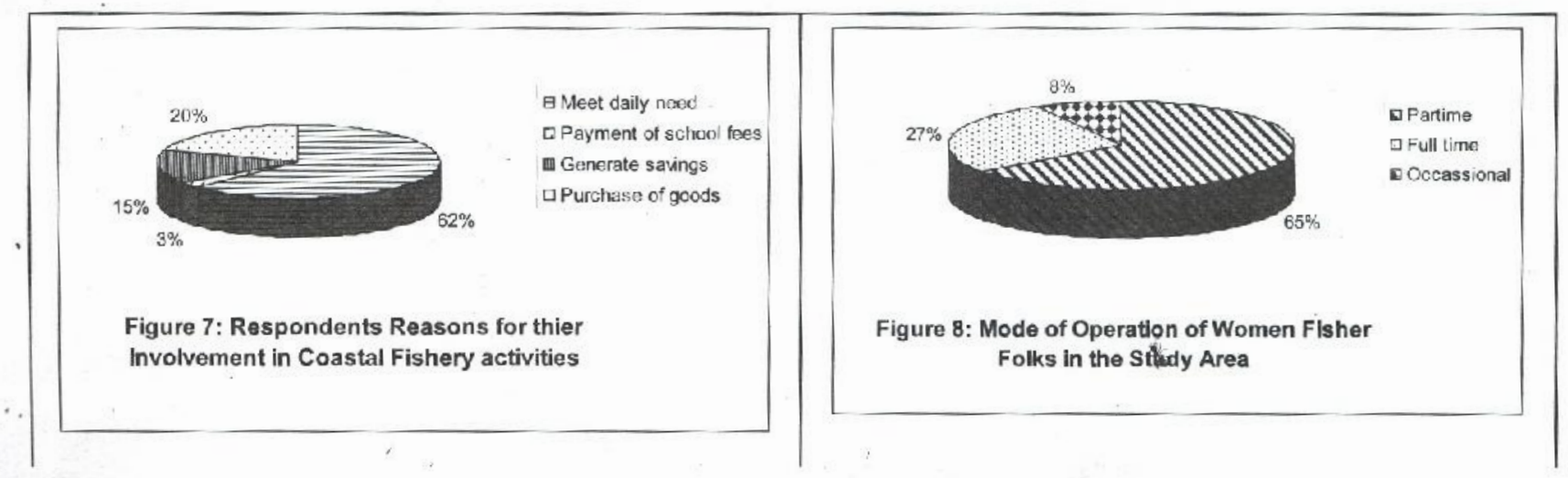

Fish were normally sold daily in fresh form (Figure 9), this is because the people in these communities have a preference for fresh fish when compared to smoked and frozen fish (Figure 9). The fish processing and preservation methods majorly $(90 \%)$ being utilized in the area is smoking (Figure 10), smoked fish are highly preserved and can easily be transferred to urban centers for sale. 


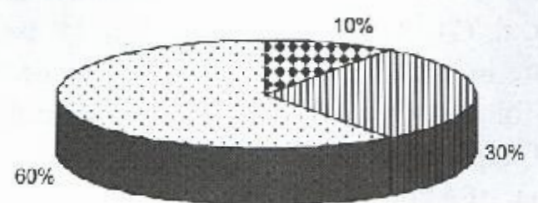

a Frozen n Smoked घFresh

Figure 9: Forms of Fish Presentation for Sale in the Study Area

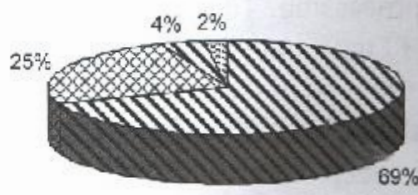

DSmoking

Q

$\checkmark$ lce Block

घSalting/Sundrying

Figure 10: Fish Processing and Preservation Methods normally practice by Fishers Folks in the Area

Different types of ovens used for smoking fish, include standing oven, mud oven, full drum and half drum oven (Figure 11). Use of drum oven full or half is not popular in the area, which could be as a result of salty nature of the environment which may lead to rusting of the metallic materials (Akinrotimi cl al., 2009). All the respondents in the area make use of standing oven in smoking their fish products. This may be due to large quantities of fish being handled at a time. The marketing strategies used in selling fish products in the area are open market display $(41 \%)$, hawking $(32 \%)$, direct purchase from fish landing sites (26\%) and packaging (1\%) (Figure 12). Most of the women employed open market display to sell their fish, while some engaged in hawking; others sell at landing site as they are returning from fishing activities.

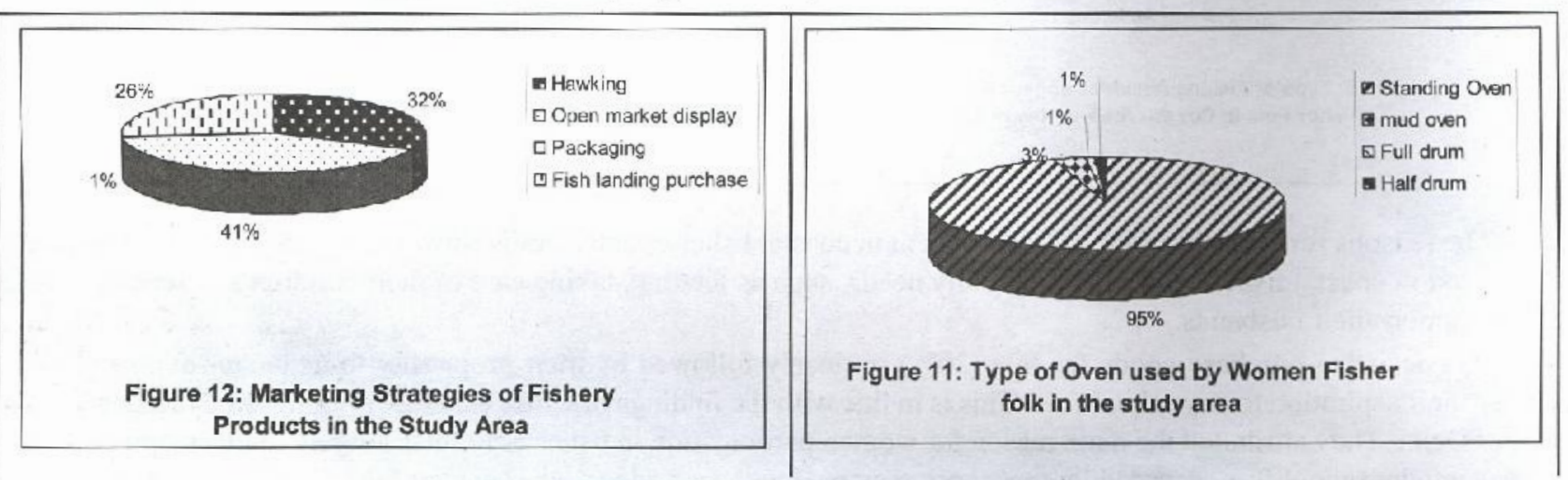

The major constraints and limitations confronting women participation in fisheries in these coastal communities as depicted in Figure 13 include lack of finance (45\%) poor transportation (15\%) network, criminal activities (25\%) lack of fishing gears, lack of cooperative society and neglect by developmental agencies, such as Niger Delta Development Commission (NDDC). According to Akinrotimi 2012, access to and availability of finance are major constraints limiting the expansion of fisheries in Niger delta region and women in fishing communities have difficulty in securing credit facilities from banks and financial institution compared to men in the same community. The upsurge of criminal activities in the area in recent times has stimulated fear in some of the women fisher folks, many are afraid of venturing into active fishing, for fear of being attacked.

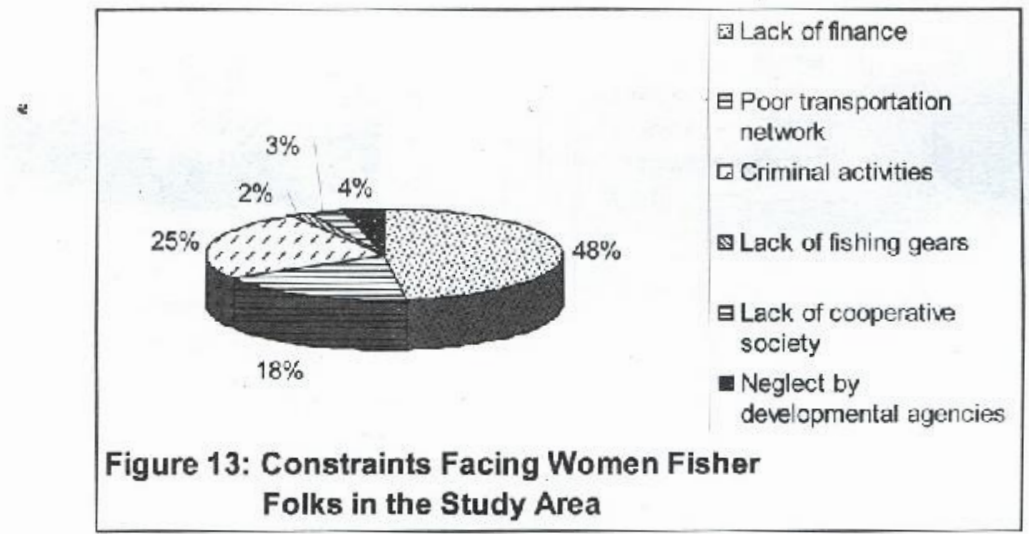

\section{Conclusion}

Even though women play a vital role in fisheries activities in the 10 coastal communities in Rivers State, their roles have not been given its proper place like men. Women are involved in fisheries in order to generate revenue that will uphold family values, using marketing and processing of fish which is crucial to enhancing nutritional values and food security. Women should be encouraged to participate fully in fisheries activities by establishing cooperative society; providing soft loans and enhancing their skills through more participatory extension programme. 


\section{REFERENCES}

Acharya, M. (2003). Efforts at promotion of women in Nepal, Kathmandu, Tanker Prasad Acharya Foundation.

Akinrotimi, O. A (2012). Issues Limiting the Expansion of Brackish Water Aquaculture in the Coastal Areas of Niger Delta. Kolo, R. J. and Orire, A. M. (eds) Proceedings, 26th FISON Annual Conference, FUT, Minna. Nov, 28-Dec.2, 169-178.

and Edun, O. M (2011). Consumer disposition towards oyster consumption in selected fishing communities of River State. Nigeria continental .Journal of Agricuitural Economics. 5/1:41-46.

Cliffe, P. T, and Ibemere, I. F (2011a). Integration of rural aquaculture into small scale farming in Niger Delta region of Nigeria. Global Approaches to Extension Practice 7/11:43 48.

, Abu, O. M. G., Themere, I. F, and Opara, C. A. (2009) Economic viability and marketing strategies of periwinkie (Tympanotonus fuseatus) in Rivers State, Nigeria. International Journal of Tropical Agricuiture and Food systems 3/3: 238-244.

Owhonda, K. N and Ibemere, I. F. (2006). Brackish water fish farming a viable option for poverty alleviation in the coastal areas of Niger Delta. Ansa, E. J., Anyanwo, P. E., Enrodu, E. S. and Deekae, S. N. (eds). Proceedings, 20th FISON Annual Conference, Port Harcourt, Rivers State, 120-125.

Abu, O. M. G and Aranyo, A. A. (2011b). Transforming aquaculture from subsistence to commercial level for sustainable development in Niger Delta region. Journal of Agriculture and Social Research 11/2:22-33.

, Orunkwu, D. N., Cliff, P. T., Anyanwo, P. E. and Orokutan, U. O. (2007). The role of fish in the nutrition and livelihond of families in Niger Delta, Nigeria. International of Tropical Agriculture and Food Systems 1/4:344 356.

Aquilar, L. (2002). Fisheries and aquaculture in coastal areas. Gender makes the difference. IUCN Briefing Notes, Geneva.

Cliffe, P. T., Akinrotimi, O. A. and Ihemere, I. F. (2011). The role of fish in improving child nutrition in Nigeria. Journal of Technology und Education in Nigeria 16/7:20 30.

Akinrotimi, O. A. and Ibemere, I. F. (2012). Promoting women participation in aquaculture as a viable tool for poverty alleviation in the rural areas of Nigeria. Global Approaches to Exiension Practice. 7/1:98-108.

Cochrane, K., De Young, C., Soto, D. and Bahri, T. (2009), Climate change implications for fisheries and aquaculture: Overview of current scientific knowledge. FAO Fisheries and Aquaculture Technical Paper No, 530, Rome: FAO, 212.

Ekpo, I. E. (2013). Women participations in lower Ikpa river fisheries of Akwa Ibom State, Nigeria: A case study of Ifiayun. Journal of Fisheries and Aquatic Science 8/1: 268-276.

FAO (1999). Guidelines for the routine collection of capture fishery data (FAO/DANIDA. Expert consultation, May 18-30 1998, Bangkok, Thailand, FAO Fisheries Technical Paper No. 382. Rome: FAO, 113.

Ibrahim, H. I., Kigbu, A. A. and Mohammed, R. (2011). Women experience in small scale fish processing in Lake Feferuwa fishing community, Nasarawa State. Livestock Research for Rural Development 23/3:1-8.

IFAD (2008). Socioeconomic and gender analysis training works hop for IFAD projects in Nigeria. International Fund for Agricultural Development, Nov. 22-26, 2004, Katsina, Nigeria.

Nwabeze, G. O., Ifejika, P. I., Tafida, A. A. and Ayanda, J. O., Eric, A. P. and Behonwo, N. E. (2013). Gender and fisheries of Lake Kainji, Nigeria. A Review Journal of Fisheries and Aquatic Science 8/1:9-13.

Obetta, N. C., Ifejiaka, P. T. and Nwabeze, G. O. (2007). Assessment of fishery content in agricultural activities of the rural women in Kukuwa LGA of Burno State. Proceedings, FISON Annual Conference, Nov. 29, 2004 Ilorin, 148-152.

Odulate, D. O., George, F. A. O. and Idowu, A. A. (2011). Role of women in fisheries in coastal wet land areas of Ogun State, southwest Nigeria. Proceedings of Environmental Management Conference, Federal University of Agriculture, Abeokuta.

Olufayo, M. (). (2012). The gender roles of women in aquaculture and food security in Nigeria. IIFET, Tamzania Proceedings. 7pp.

Tamale, S. (2004). Gender trauma in Africa: Enhancing women's likely to resources. Journal of Africa law 48/1:50-61.

Williams, S. B. (2006). The sociocconomic potentials of women in riverine small-scale fisheries in Nigeria. PhD Thesis, Dept. of Agric Econ., Obafemi Awolowo University, Ile-Ife, Osun State. 